\title{
Memikirkan Ulang Peran Youth Pastor sebagai Pembuat Murid dalam Pelayanan Kaum Muda
}

\author{
Ronny Christian ${ }^{1}$
}

\section{Pendahuluan}

- ersedianya banyak literatur dan kurikulum bagi pelayanan kaum muda di saat ini menandakan bahwa pelayanan ini sedang mengalami perkembangan yang signifikan. Berbagai literatur tersebut memberikan pencerahan tentang bagaimana seharusnya pelayanan kaum muda itu dipandang dalam pelayanan gerejawi secara keseluruhan. Dalam hal ini, Pusat Studi dan Pengembangan Pelayanan Kaum Muda (PSPPKM) STT Amanat Agung juga ikut melengkapi dengan memaparkan sejumlah penelitian yang memberitahukan kepada kita bagaimana kondisi nyata dari pelayanan yang dilakukan oleh gereja-gereja di Indonesia dalam konteks tertentu.

Salah satu penelitian yang dilakukan tersebut menyoroti peran dari youth pastor di enam gereja berlatar belakang injili Tionghoa yang berada di Jakarta. Dalam penelitian tersebut ditemukan bahwa yang mendorong seorang kaum muda untuk terlibat aktif di gereja adalah teman, kemudian kakak senior atau orang yang lebih dewasa, dan di urutan ketiga adalah youth pastor. "Nampaknya rohaniwan kaum muda bukanlah menjadi tokoh yang banyak disebut oleh responden dalam mengemukakan bagaimana komunitas telah membentuk mereka", begitu kesimpulan dari Astri Sinaga yang menggagas penelitian etnografi tersebut. Jika demikian halnya apakah peran youth pastor tidak diperlukan lagi di dalam gereja? Secara jelas, sang penggagas penelitian itu menerangkan bahwa kehadiran youth pastor tetap vital karena perannya yang memberi arah dan makna dari seluruh kegiatan komunitas kaum muda di gereja. Bahkan tanpa keterlibatan yang nyata dari seorang youth pastor 
maka tidak ada pertumbuhan kerohanian yang nyata dari kaum muda yang ada di gereja tersebut. ${ }^{2}$

Itulah sebabnya saya memandang penting untuk membahas keberadaan youth pastor sebagai pribadi yang tidak hanya bertindak sebagai pemberi makna rohani dalam kegiatan komunitas kaum muda di gereja namun juga sebagai pribadi yang menghasilkan murid bagi Kristus. Bagi saya keberadaan youth pastor sebagai murid Kristus yang juga memuridkan kamu muda untuk menjadi murid Kristus adalah identitas dari youth pastor itu sendiri.

\section{Gereja Cenderung tidak Memuridkan Kaum Muda}

Dalam penelitian PSPPKM yang saya sebutkan di atas, kegiatan di dalam komunitas kaum muda di gereja itu dapat dibagi menjadi 4: pertama, kegiatan yang bersifat natural pertemanan, seperti: jalan-jalan, makan bersama, nonton bareng; kedua, Kegiatan yang berdasarkan minat, misalnya: olah raga, fotografi, multimedia; ketiga, kegiatan yang terkait dengan persiapan ibadah; dan yang keempat, kegiatan yang terkait dengan pembinaan dan pemuridan. Dari keempat jenis kegiatan tersebut mana yang mendominasi kegiatan di komunitas kaum muda di gereja Anda? Kegiatan mana yang seharusnya mendominasi pelayanan kaum muda kita?
Semua kegiatan ini memberikan kontribusi tertentu bagi kemajuan pelayanan kaum muda. Namun perhatikan kesimpulan dari penelitian berdasarkan kegiatan-kegiatan tersebut ${ }^{3}$

"Bila diamati lebih mendalam, lebih banyak dari mereka yang mengatakan hal-hal baru yang muncul dalam diri mereka lebih bersifat 'keterampilan', 'karakter' dan 'sikap-sikap' daripada hal-hal yang bersifat spiritual seperti 'pengenalan kepada Allah', atau 'pemahaman dan konsep Kekristenan' ataupun 'kedewasaan rohani'. Memang didapati ada yang mengatakan "saya belajar melayani untuk Tuhan", tetapi ungkapan semacam ini - yang sebenarnya menunjukkan suatu kesadaran rohani yang sangat mendasar - sangat sedikit sekali."

Kesimpulan tersebut mengindikasikan bahwa pelayanan kaum muda di gereja cenderung tidak berhasil untuk membawa kaum muda untuk menjadi murid Kristus yang sejati. Semua kegiatan-kegiatan tersebut tampaknya berdiri sendiri dan tidak berbeda dari kelompok sosial kaum muda lainnya. Inilah gambaran dari komunitas remaja pemuda dari gerejagereja yang saya yakin menginginkan jemaatnya bertumbuh serupa Kristus namun dalam praktik pelayanan yang ada justru menciptakan pertumbuhan yang tidak menyerupai Kristus. Seperti yang ditulis oleh Edmund Chan, menurut John

2. Astri Sinaga, “Komunitas Kaum Muda Gereja: Studi Etnografi Komisi Remaja-Pemuda di Gereja Injili-Tionghoa di Jakarta," Jurnal Youth Ministry 2 (November 2014): 73-81.

3. Sinaga, "Komunitas Kaum Muda Gereja: Studi Etnografi Komisi Remaja-Pemuda di Gereja Injili-Tionghoa di Jakarta," 77.

\section{Youlfh}




\section{Pendekatan teknologi adalah pendekatan yang dilakukan untuk memecahkan berbagai masalah fungsional yang diharapkan akan meningkatkan hasil yang diinginkan. Masalah fungsional yang ada di gereja adalah masalah komitmen religius yang rendah Canak- anak tidak menyukai gereja] dan masalah perilaku moralitas.}

Stott gambaran orang Kristen yang seperti ini dapat disimpulkan dalam 3 kata: pertumbuhan tanpa kedalaman. ${ }^{4}$

Hasil penelitian in i harusnya menjadi sebuah peringatan untuk rohaniwan kaum muda untuk kembali memikirkan perannya sebagai seorang hamba Tuhan yang dipanggil untuk meneruskan Amanat Agung Tuhan Yesus bagi generasi muda.

\section{Jebakan bagi Youth Pastor}

Lalu pertanyaannya, mengapa seorang youth pastor bisa tidak memfokuskan dirinya untuk memuridkan remaja dan pemuda yang ia layani? Saya berasumsi itu bermula dari ekspektasi yang keliru dari gereja terhadap youth pastor.

Saya memiliki kesempatan untuk melayani sebagai youth pastor di beberapa gereja yang berlatar belakang gereja injili Tionghoa, dan informasi awal yang sering diberitahukan kepada saya adalah berkaitan dengan jumlah kedatangan yang menurun dari persekutuan remaja dan persekutuan pemuda di gereja tersebut. Atau jumlah kehadiran dalam kondisi yang baik, tetapi diharapkan jumlah kehadiran bisa terus meningkat. Jadi, salah satu tugas seorang youth pastor adalah bisa membuat angka kehadiran bertambah. Majelis gereja akan meminta saya untuk membuat sesuatu yang menarik sehingga tidak hanya anak mereka tetapi juga remaja atau pemuda lainnya mau hadir di dalam persekutuan remaja pemuda. Lalu apa yang saya lakukan? Saya berusaha untuk membuat tema-tema firman Tuhan yang menarik bagi kaum muda, lalu juga membuat seminar, membuat acara outing, outbound, acara lomba masak, dan sejumlah acara lainnya yang dapat membuat angka kehadiran bertambah. Makin banyak yang hadir maka makin sukses pelayanan yang saya lakukan. Apakah mereka bertumbuh di dalam kedewasaan rohani? Pertanyaan seperti ini tidak pernah muncul dalam setiap evaluasi kegiatan yang dilakukan. Inilah kondisi umum dalam pelayanan kaum muda yang ada di gereja.

Kondisi kehadiran yang menurun seperti ini membawa youth pastor untuk memikirkan solusinya. Atau lebih tepat menemukan "bagaimana caranya" mendongkrak angka kehadiran. Pola pikir "bagaimana caranya" ini yang mungkin kemudian mendominasi pemikiran youth

4. Edmund Chan, Kemuridan Radikal: Lima Pertanyaan Penting (Singapore: Covenant Evangelical Free Church, 2014 ), 73. 
pastor di gereja injili dalam melayani di pelayanan kaum muda. Duffy Robbins menyebutkan bahwa pola pikir seperti ini adalah pola pikir yang mementingkan "bagaimana" (how), dan bukan "apa" (what) dan mengapa (why). Tidak salah memang ketika kita bertanya tentang sesuatu yang praktis untuk bisa diterapkan dalam pelayanan. Namun sebelum sampai pada penerapan kita perlu bertanya sesuatu yang lebih fondasional, yaitu pertanyaan yang diawali dengan apa dan mengapa pelayanan kaum muda ini ada? Apa peran utama saya sebagai youth pastor dalam komunitas di gereja ini? Pertanyaan mengapa adalah pertanyaan yang membawa seorang pelayan kaum muda untuk menemukan tujuan dan pondasi dari pelayanan yang dia akan lakukan. Saya setuju dengan penjelasan Duffy: "Youth workers are far more concerned about how than what or whytechnique is what captures the imagination, not what should we be doing or why are we doing it. But how without why is empty and bankrupt." ${ }^{5}$ Kata "empty and bankrupt" mewakili spiritualitas kaum muda hari ini yang kosong makna.

Pendekatan seperti inilah yang disebut oleh Andrew Root sebagai pendekatan teknologi. Pendekatan teknologi adalah pendekatan yang dilakukan untuk memecahkan berbagai masalah fungsional yang diharapkan akan meningkatkan hasil yang diinginkan. Masalah fungsional yang ada di gereja adalah masalah komitmen religius yang rendah (anak-anak tidak menyukai gereja) dan masalah perilaku moralitas. Jika semakin banyak kaum muda yang hadir di gereja dan mereka memiliki perilaku moral yang baik maka pelayanan kaum muda di gereja tersebut dinilai berhasil. Dalam pendekatan teknologi, seorang youth pastor akan dituntut untuk terus menghasilkan program, event-event yang dapat menarik kaum muda. ${ }^{6}$ Pada akhirnya, bisa saja seorang youth pastor akan terjebak pada pelayanan kaum muda yang berbasis pada program (program driven) dan pelayanan yang berbasis pada hiburan (entertainment driven). Dengan kata lain, tanpa sadar kita masih menyebut diri sebagai youth pastor namun dalam kenyataan kita adalah seorang youth programmer atau bahkan event organizer.

Bagi saya ini adalah sebuah jebakan dalam pelayanan saya sebagai youth pastor. Saya bisa terjebak untuk membangun identitas keberhasilan pelayanan pada standar yang diciptakan oleh manusia. Saya akan merasakan happy jika angka kehadiran di persekutuan remaja pemuda meningkat, dan sebaliknya akan merasa frustasi jika sampai berbulanbulan angka kehadirannya berkurang. Sekali lagi saya tidak mengatakan bahwa pertambahan jumlah tidaklah penting. Yang ingin saya katakan adalah angka kehadiran bukanlah barometer yang

5. Duffy Robbins, Building a Youth Ministry that Builds Disciples: A Small Book About a Big Idea (Grand Rapids: Zondervan/Youth Specialties, 2012), edisi Kindle.

6. Andrew Root, Bonhoeffer sebagai Pelayan Kaum Muda: Visi Teologis untuk Pemuridan dan Hidup Bersama, terj. Hendro Lim dan Fora Setia (Jakar Sekolah Tinggi Teologi Amanat Agung, 2017), 5-6.

\section{Youlfh}


benar di dalam menentukan keberhasilan pelayanan kita dihadapan Allah. Ini bukan arah yang Allah berikan ketika memanggil kita sebagai hamba-Nya. Arah yang Allah berikan adalah membawa orang lain untuk menjadi murid-Nya, mengasihi Allah dan mengasihi sesama. Ini adalah Amanat Agung yang Tuhan Yesus yang harus dikerjakan oleh rohaniwan kaum muda di dalam pelayanan yang ia kerjakan. Dengan demikian pelayanan kaum muda di gereja betul-betul menjadi komunitas murid Kristus.

\section{Memahami Pendekatan yang Tepat sebagai Pembuat Murid Kristus}

Pendekatan teknologi harus diganti dengan pendekatan teologis jika seorang youth pastor mau menjadikan dirinya sebagai pembuat murid bagi Kristus. Andrew Root dan Kenda Creasy Dean adalah pakar dalam pelayanan kaum muda yang mengusung pendekatan ini. Pendekatan beralih kepadayang teologis adalah "pendekatan yang melihat pelayanan kaum muda sebagai wadah perjumpaan dengan wahyu Allah dan kemanusiaan orang muda (yang teologis)." 7 Dalam pendekatan teologis seorang youth pastor berusaha untukmelihat pekerjaan Tuhan di dalam diri kaum muda dan berpartisipasi dalam pekerjaan Allah tersebut. Pendekatan teologis berbeda dengan beralih kepada teologi. Lengkapnya Andrew Root membedakan pendekatan teknologi, beralih kepada teologi (turn to theology) dan pendekatan yang beralih pada yang teologis (turn to theological), sebagai berikut: ${ }^{8}$

"Sebuah pelayanan kaum muda yang beralih kepada teologi berusaha mendorong kaum muda kepada bentuk-bentuk pengetahuan formal (untuk mengasimilasi doktrin). Sebuah pelayanan kaum muda yang terikat pada teknologi berusaha meningkatkan jumlah dan mengubah perilaku. Sedangkan pelayanan kaum muda yang beralih kepada yang teologis berusaha berbagi pengalaman konkret dan hidup dari kaum muda sebagai tempat yang tepat untuk berbagi tindakan dan keberadaan Allah."

Saya menempatkan pendekatan yang beralih pada yang teologis sebagai kunci yang harus dipahami seorang youth pastor karena adanya kecenderungan untuk memahami pemuridan sebagai pengajaran firman Tuhan berupa doktrin yang diharapkan dapat membuat seseorang bertumbuh di dalam kerohaniannya. Menurut saya ini bukan model pemuridan yang Tuhan Yesus berikan kepada kita. Pemuridan bukanlah proses transfer informasi melainkan proses transformasi hidup yang semakin serupa dengan Kristus. Kita tidak bisa berharap bahwa semakin banyak seseorang mengetahui kebenaran firman Tuhan maka secara otomatis hidupnya akan mengalami perubahan yanag Allah inginkan. Jika mendengarkan firman Tuhan saja

7. Root, Bonhoeffer sebagai Pelayan Kaum Muda, 7.

8. Root, Bonhoeffer sebagai Pelayan Kaum Muda, 8. 


\section{Dalam pendekatan teologis,} seorang youth pastor akan menempatkan dirinya sebagai murid Kristus yang berbagi hidup dan berbagi kebenaran firman Tuhan serta berusaha untuk menghidupi kebenaran tersebut bersama-sama dengan remaja pemuda yang ia gembalakan. Di dalam relasi inilah proses membuat murid tersebut dimulai.

bisa mengubahkan kehidupan seseorang maka Tuhan Yesus tidak akan mengajarkan perumpamaan tentang Orang Yang Bodoh dan Orang Yang Bijaksana di dalam Matius 7:24-27. Saya setuju dengan pernyataan Edmund Chan yang mengatakan: "Kebenaran itu tidak mengubahkan hidup. Kebenaran yang diterapkan, itulah yang mengubahkan hidup." ${ }^{\prime \prime}$ Hasil akhir dari pemuridan bukanlah memiliki pengetahuan melainkan ketaatan untuk melakukan kehendak Allah di dalam hidup kita. Chris Folmsbee dalam bukunya $A$ New Kind of Youth Ministry, juga mengatakan hal yang serupa: ${ }^{10}$

“Students' lives don't change just from learning more and more informationeven if that information is all true and all about God. We may be the greatest communicators on the planet-creative, charismatic, clear, compelling, comical-but that doesn't guarantee our students are connecting with what it really means to be a developing follower of Jesus. Discipleship is not solely about learning more about God. It's about learning how to live one's life to glorify God."

Jadi dalam pendekatan teologis, seorang youth pastor akan menempatkan dirinya sebagai murid Kristus yang berbagi hidup dan berbagi kebenaran firman Tuhan serta berusaha untuk menghidupi kebenaran tersebut bersama-sama dengan remaja pemuda yang ia gembalakan. Di dalam relasi inilah proses membuat murid tersebut dimulai.

Menjalani Kehidupan sebagai Pembuat Murid bagi Kristus

Bagaimana seorang youth pastor harus memulai proses pemuridan dalam pelayanannya? Pertanyaan ini juga yang muncul di dalam benak saya ketika saya disadarkan tentang identitas diri saya sebagai pembuat murid bagi Kristus. Tahap awal yang menurut saya penting adalah memahami fondasi teologis dan definisi yang berkaitan dengan pemuridan. Dalam hal ini Matius 28:19-20 menjadi dasar yang jelas sebagai sebuah amanat yang Allah berikan untuk kita kerjakan. Ini adalah kebenaran dan pe-

9. Chan, Kemuridan Radikal, 91.

10. Chris Folmsbee, A New Kind of Youth Ministry (El Cajon, CA: Zondervan/Youth Specialties, 2007), edisi Kindle. 
rintah yang harus menjadi sebuah realita di dalam hidup pelayanan seorang youth pastor.

Dalam teks Yunaninya Matius 28:1920 hanya memiliki satu kata kerja imperatif, yaitu: jadikan lah murid. Jadi dalam Amanat-Nya Tuhan Yesus hanya meminta murid-murid-Nya melakukan perintah tunggal, yaitu murid-murid-Nya harus mencari orang lain dan menjadikannya murid Tuhan Yesus. Perintah ini lalu diikuti participial phrases (frasa-frasa yang berkaitan), yang menerangkan cara kita membuat murid: pergilah, baptislah dan ajarlah melakukan segala sesuatu yang sudah diajarkan Tuhan Yesus. Bobby Harrington menjelaskan frasa-frasa yang berkaitan itu sebagai sebuah penjelasan untuk menolong orang lain percaya kepada Yesus sebagai Tuhan dan mengikutinya dengan taat melakukan apa yang dikehendaki oleh Allah. ${ }^{11}$ Kemudian Harrington juga memberikan definisi tentang murid, membuat dan pembuat murid sebagai berikut: ${ }^{12}$

- Murid (a disciple): orang yang mengikut Yesus, diubahkan oleh Yesus, dan taat melakukan misi Yesus.

- Membuat Murid (disciple making): menolong orang untuk percaya dan mengikut Yesus.

- Pembuat Murid (disciple maker): Seorang Kristen yang masuk ke dalam hubungan dengan orang- orang untuk membantu mereka percaya dan mengikuti Yesus.

Sekilas memang definisi di atas adalah sebuah definisi yang sederhana, tetapi definisi tersebut sangat menolong kita memahami identitas diri dalam melaksanakan Amanat Agung yang diberikan Tuhan Yesus. Berdasarkan definisi tersebut, maka sebagai pembuat murid, saya harus menyediakan diri untuk masuk ke dalam kehidupan orang lain dengan tujuan membantu mereka untuk percaya dan mengikuti Yesus. Masuk ke dalam hidup orang lain itu berarti saya harus belajar tidak hanya menyediakan waktu untuk orang lain, namun juga saya harus belajar bagaimana saya bisa menerima dan diterima oleh orang tersebut. Relasi antar sesama adalah pintu masuk agar kita dapat membantu mereka.

Edmund Chan dalam bukunya Kemuridan Radikal, melengkapi pemahaman kita bahwa arti mengikut Yesus sepenuhnya memiliki 3 hal: mengenal Yesus, mengasihi Yesus, dan melayani Yesus. ${ }^{13}$ Ini yang disebut oleh Harrington sebagai 3 as pek kunci pemuridan di dalam Perjanjian Baru: ${ }^{14}$

i. "Mengikut" Yesus (kepala).

ii. "Diubahkan" oleh Yesus melalui Roh Kudus (hati).

iii. Taat melakukan misi Yesus, yaitu menjadi "penjala manusia" (tangan).

11. Penjelasan tentang Matius 28:19-20 ini sebenarnya cukup umum dijelaskan dalam berbagai buku yang membahas tentang pemuridan. Namun menurut hemat saya dijelaskan dengan baik dan praktis dalam buku yang ditulis oleh Bobby Harrington dan Josh Patrick, Buku Panduan Pembuat Murid: 7 Aspek Gaya Hidup Pemuridan (Yogyakarta: Penerbit Katalis, 2017 ), 45.

12. Harrington dan Patrick, Buku Panduan Pembuat Murid, 44-46.

13. Chan, Kemuridan Radikal, 103.

14. Harrington dan Patrick, Buku Panduan Pembuat Murid, 44. 
Istilah kepala, hati, dan tangan menunjuk bahwa pemuridan berkaitan dengan keseluruhan aspek kehidupan dari manusia. Pemahaman ini membawa kita mengerti bahwa pelayanan menjadikan orang lain sebagai murid Kristus adalah proses yang tidak mudah, dan merupakan sebuah helping ministry yang sangat holistik sekaligus powerful jika betul-betul diterapkan di dalam pelayanan kaum muda di gereja.

Fondasi teologis dari pembuat murid itu seharusnya diikuti oleh tahap kedua, yaitu bangkitnya kesadaran diri sebagai seorang pembuat murid di dalam diri youth pastor. Tanpa kesadaran diri ini maka proses pemuridan di dalam komunitas kaum muda yang digembalakannya tidak terjadi. Fondasi teologis tersebut hanya akan dipahami tetapi tidak dihidupi. Kesadaran diri ini kemudian diikuti oleh disiplin rohani, dalam membaca dan merenungkan firman Tuhan, berdoa serta berlatih menghidupi firman Tuhan. Disiplin rohani tidak boleh menjadi sesuatu yang bersifat legalis dan kering, melain kan menjadi sesuatu yang hidup dalam diri youth pastor. Dalam hal in $\mathrm{i}$ penting juga untuk mencari seorang mentor rohani yang bersedia menyediakan waktunya untuk saling berdoa dan berdiskusi berkaitan kehidupan pribadi dan tentang pelayanan. Inti dari mem- bangun kehidupan yang seperti ini adalah membangun kedewasaan rohani dalam mengikut Yesus sepenuhnya (Yoh. 15:58). Ini adalah proses yang terus berkesinambungan di dalam hidup seorang youth pastor.

Kehidupan mengikuti Kristus sebagai murid yang bersifat progresif inilah yang saya impartasikan ke dalam hidup kaum muda yang saya layani. Keberadaan diri kita sebagai murid Kristus memang bukanlah teladan terbaik, namun sebagai pembuat murid keteladanan hidup adalah sesuatu yang dituntut dan menjadi salah satu kunci keberhasilan di dalam pemuridan. Ini adalah bag ian dari teaching them to obey dalam Amanat Agung untuk menjadikan mereka murid Kristus. Saya tidak mungkin mengajarkan mereka un tuk menjadi murid Kristus yang taat jika saya sendiri tidak memiliki kehidupan murid Kristus yang taat. Mengenai keteladanan Albert Schweitzer, seorang dokter misionaris yang melayani di Afrika itu pernah berkata: "Teladan bukanlah hal utama dalam memengaruhi orang lain-itu satusatunya hal yang memengaruhi orang."15

Tahap ketiga adalah memahami gambaran besar dari proses membuat murid itu sendiri. Dalam buku panduan pemuridannya, Perkantas memberikan gambaran besar proses pelayanan pemuridan sebagai berikut: ${ }^{16}$

15. Dikutip oleh Scott Morton, Pemuridan untuk Semua Orang (Yogyakar Penerbit Yayasan Gloria, 2011 ), 102.

16. Tim Staf Perkantas, Pemuridan Dinamis Membangun Bangsa: Memuridkan Berbasis Kelompok Kecil dan Profil (Jakarw: Literatur Perkantas, 2013), 38-39.

\section{2 moulf}




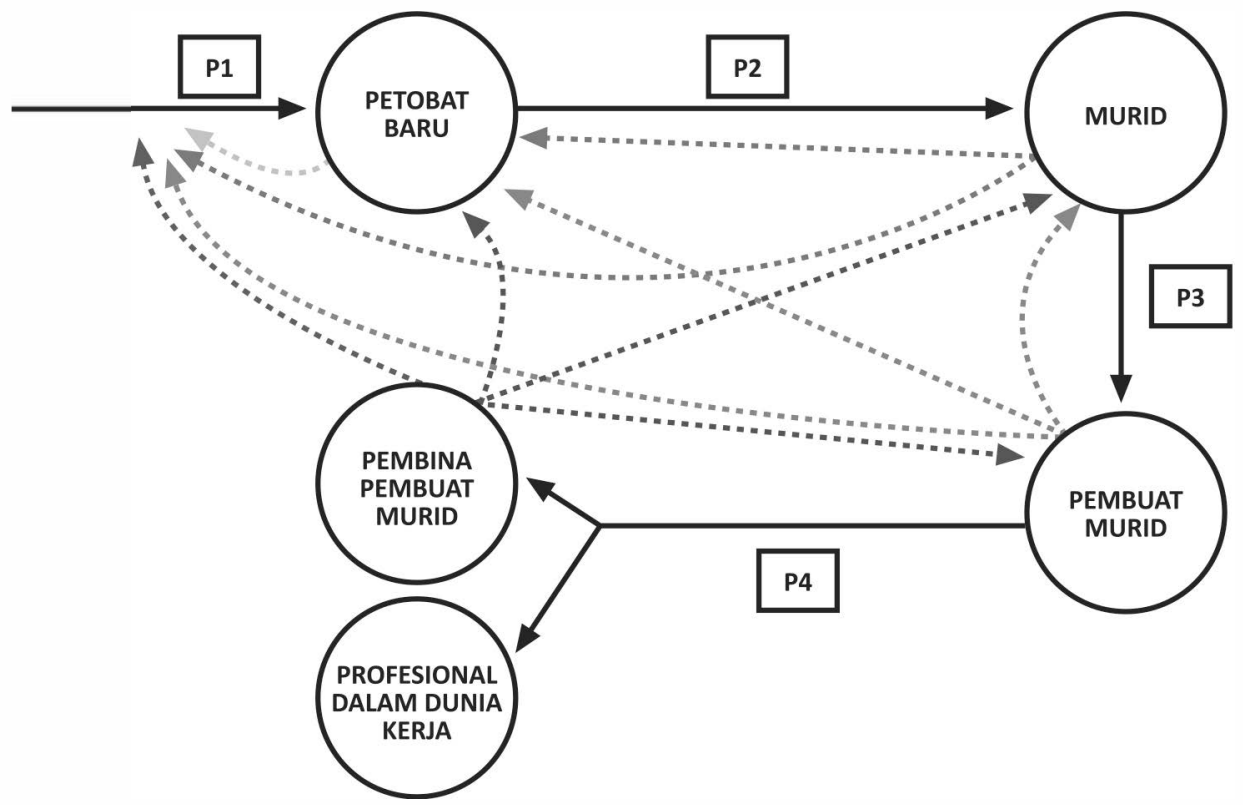

Proses pemuridan tersebut melingkupi P1 (Penginjilan), P2 (Pembinaan), P3 (Pelipat Gandaan), dan P4 (Pengutusan). Tanda panah dengan garis lurus $(\rightarrow)$ adalah arah pertumbuhan seseorang dalam pemuridan, sedangkan tanda panah dengan garis terputus-putus $(\rightarrow$ ) adalah kemampuan penjangkauan oleh:

- Petobat Baru mampu melakukan penginjilan kepada yang belum percaya.

- Murid mampu melakukan penginjilan hingga menjadikannya Petobat Baru.

- Pembuat Murid mampu melakukan penginjilan hingga menjadikannya murid

- Pembina Pembuat Murid mampu melakukan penginjilan hingga menjadikannya Pembuat Murid.

- Profesional: murid melayani yang memiliki kepemimpinan dan pe- ngaruh di masyarakat yang diutus masuk ke dunia profesional.

Jika kita memakai proses pemuridan ini maka jelas seorang youth pastor seharusnya dalam posisi sebagai Pembina Pembuat Murid Itu berarti secara pribadi dia telah dilatih dan mampu melakukan penginjilan sampai pengutusan. Ini adalah gambaran ideal dari proses pemuridan. Melalui gambaran besar proses pemuridan ini, seorang youth pastor dapat merancang strategi dan pelatihan-pelatihan yang pada akhirnya menghasilkan profil murid Kristus yang secara berkesinambungan akan menghasilkan murid Kristus lainnya.

Tahapan yang saya tuliskan di sini adalah tahapan yang saya pikir dapat menolong seorang youth pastor untuk memikirkan ulang peranannya sebagai pembuat murid. Selanjutnya dalam tatanan praktisnya, adalah memulai pendekatan pribadi dengan satu atau beberapa kaum 


\section{Dalam pengalaman saya, pemuridan secara personal ini yang kemudian akan menjadi awal perkembangan pelayanan pemuridan di dalam kelompok. Inilah yang akan kita lakukan sebagai youth pastor, sembari kita juga melakukan tugas tanggung jawab pelayanan yang lainnya sebagai rohaniwan gereja.}

muda, yang kemudian diikuti dengan membentuk kelompok-kelompok kecil pemuridan. Orang-orang yang dipilih akan lebih baik jika orang-orang tersebut adalah yang memiliki kehausan akan firman Tuhan. Dawson Trotman, pendiri Navigators, seperti yang dikutip oleh Scott Morton, memberikan pertanyaan pengarah untuk kita melakukan pemuridan: "Di manakah orangmu? Di manakah satu orang yang kepadanya engkau mencurahkan kehidupanmu untuk menolong mereka berjalan bersama dengan Kristus?"17 Dalam pengalaman saya, pemuridan secara personal ini yang kemudian akan menjadi awal perkembangan pelayanan pemuridan di dalam kelompok. Inilah yang akan kita lakukan sebagai youth pastor, sembari kita juga melakukan tugas tanggung jawab pelayanan yang lainnya sebagai rohaniwan gereja.

\section{Penutup}

Frank Viola dalam booklet Discipleship in Crisis menceritakan bahwa pada saat ia berumur 20 tahunan, hampir semua gereja dan organisasi Kristen memiliki program pemuridan, tetapi masalahnya adalah sangat sedikit transformasi yang terjadi di dalam diri orang-orang yang mengikuti pemuridan. Menurutnya saat ini terjadi repetisi, di mana gereja-gereja berusaha menghidupkan lagi pemuridan di dalam gereja. Yang menjadi pertanyaan: apakah akan terjadi transformasi dalam kehidupan orang-orang ini?18 Pertanyaan ini jugalah yang harus kita jawab sebagai youth pastor ketika kita memikirkan ulang peran kita sebagai pembuat murid. Bila tidak terjadi perubahan hidup yang semakin serupa dengan karakter Kristus di dalam diri kita dan di dalam diri orangorang yang kita muridkan, maka tentu kita harus memikirkan ulang kembali motivasi, strategi, cara pendekatan, metode pemuridan yang kita lakukan. Saya yakin jika pemuridan menjadi visi yang dilakukan dan bukan sekadar visi yang dikonsepkan maka perubahan hidup dalam diri orang-orang yang kita layani akan terlihat nyata.

17. Morton, Pemuridan untukSemua Orang, 20-21.

18. Frank Viola, Discipleship in Crisis: 9 Reasons Why Discipleship isn't Working Today Problems and Solutions, http://frankviola.org/dic7714.pdf (diakses 6 Desember 2017).

\section{4}

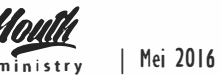




\section{Daftar Pustaka}

Chan, Edmund. Kemuridan Radikal: Lima Pertanyaan Penting. Singapore: Covenant Evangelical Free Church, 2014.

Folmsbee, Chris. A New Kind of Youth Ministry. El Cajon, CA: Zondervan/Youth Specialties, 2007. Edisi Kindle.

Harrington, Bobby dan Josh Patrick. Buku Panduan Pembuat Murid: 7 Aspek Gaya Hidup Pemuridan. Yogyakarta: Penerbit Katalis, 2017.

Morton, Scott. Pemuridan untuk Semua Orang. Yogyakarta: Penerbit Yayasan Gloria, 2011.

Robbins, Duffy. Building a Youth Ministry that Builds Disciples: A Small Book About a Big Idea. Grand Rapids: Zondervan/Youth Specialties, 2012. Edisi Kindle.

Root, Andrew. Bonhoeffer sebagai Pelayan Kaum Muda: Visi Teologis untuk Pemuridan dan Hidup Bersama. Diterjemahkan oleh Hendro Lim dan Fora Setia. Jakarta: Sekolah Tinggi Teologi Amanat Agung, 2017.

Sinaga, Astri. “Komunitas Kaum Muda Gereja: Studi Etnografi Komisi Remaja-Pemuda di Gereja Injili-Tionghoa di Jakarta." Jurnal Youth Ministry 2 (November 2014): 73-81.

Tim Staf Perkantas, Pemuridan Dinamis Membangun Bangsa: Memuridkan Berbasis Kelompok Kecil dan Profil. Jakarta: Literatur Perkantas, 2013.

Viola, Frank. Discipleship in Crisis: 9 Reasons Why Discipleship isn't Working Today Problems and Solutions. http://frankviola.org/dic7714.pdf (diakses 6 Desember 2017). 